\title{
Breast cancer and support group in the life of mastectomized women
}

\author{
Câncer de mama e grupo de apoio na vida \\ da mulher mastectomizada
}

Elisa da Luz Adorna, Elhane Glass Morari-Cassol, Nara Maria Severo Ferraz*

Universidade Federal de Santa Maria, Santa Maria, RS, Brazil

\begin{abstract}
Objectives: To identify the importance of participation in support groups for mastectomized women's recovery and their knowledge about this type of cancer. Material and methods: Qualitative descriptive study with ten mastectomized women participants of the "Reborn" ("Renascer", in portuguese) support group. Data were collected by means of interviews, using a questionnaire prepared by the researcher as an instrument. The data collected were then qualitatively analyzed according to the systematization proposed by Minayo (4). Results: Six categories were identified. This study addressed the knowledge of the participants on breast cancer and their participation in the support group. Conclusion: A change of concepts and ideas about cancer in the interviewed women was identified, as well as the importance of information and explanation about this cancer, its treatment and consequences for the patient. The relevance of the support group in these women's recovery is also noteworthy, due to the opportunity of socializing with other people with similar stories.
\end{abstract}

Keywords: Breast neoplasms. Mastectomy. Women's health.

* ELA: grad., e-mail: elisa_adorna@hotmail.com EGMC: PhD, e-mail: elhanegmc@gmail.com NMSF: PhD, e-mail: nsferraz@gmail.com 


\section{Resumo}

Objetivos: Identificar a importância da participação em grupo de apoio para a recuperação da mulher mastectomizada e seu conhecimento sobre o câncer. Métodos: Realizou-se um estudo descritivo de caráter qualitativo, com 10 mulheres mastectomizadas participantes do grupo de apoio Renascer. A coleta de dados deu-se por meio de entrevista, tendo como instrumento um questionário elaborado pela pesquisadora. Os dados foram posteriormente analisados de forma qualitativa conforme proposta de sistematização de Minayo (4). Resultados: Foram identificadas seis categorias, neste artigo serão abordadas as categorias conhecimento sobre o câncer de mama e participação no grupo de apoio. Conclusão: Identificou-se uma mudança de conceitos e ideias sobre o câncer por parte das mulheres entrevistadas, e a importância da informação e explicação sobre o câncer, seu tratamento e consequências para a paciente. Salienta-se, também, a importância do grupo de apoio na recuperação dessas mulheres, pela oportunidade de convívio com outras pessoas com histórias semelhantes.

Palavras-chave: Neoplasias da mama. Mastectomia. Saúde da mulher.

\section{Introduction}

Breast cancer is the second most common cancer worldwide and the most common among women. A total of 49,240 new cases were expected in 2010 in Brazil, with an estimated risk of 49 cases per 100,000 women, and an estimate of 49.58 cases per 100,000 women in Rio Grande do Sul (1).

The diagnosis of any cancer causes fear and apprehension as it is often seen as a death sentence. Breast cancer treatment includes surgery, chemotherapy, radiotherapy and/or hormone therapy and might cause serious physical and psychological consequences that vary according to the type of treatment (2).

Breasts are related to femininity, sexuality and maternity. A mastectomy can affect a woman's identity and reverberate in their personal, emotional, family and social life, self-esteem and bodily image.

The physical therapist, along with other health professionals, must identify the impact of breast cancer and its treatment, especially in relation to the body and women's interpersonal relationships, besides physical consequences, to understand the needs and difficulties of mastectomized women. The interference of these factors may manifest not only during treatment or immediately after, but also in a later period, as these women may live many years and might have to readapt to seek better quality of life.

Based on the above, the aim of this study was to verify mastectomized women's knowledge about aspects related to the disease and identify the importance of their participation in support group for recovery.

\section{Material and methods}

A descriptive, prospective study with qualitative data analysis was conducted.

This study is part of a research project entitled " $A$ mastectomia e suas repercussões na vida da mulher", approved by the research ethics committee of the Federal University of Santa Maria under approval certificate CAAE No. 0163.0.243.000-09. The present study will address an analysis related to the knowledge of mastectomized women about breast cancer and its aspects and participation in the support group.

The study group consisted of ten women undergoing mastectomy for breast cancer, all participants of the support group for breast cancer patients from the teaching hospital of Santa Maria - the "Reborn" group.

Inclusion criteria were: being aged over 18 years, having undergone surgery for over a year and being a participant of the "Reborn" group.

Exclusion criteria were: being aged age under 18, having comprehension difficulties and being on chemotherapy or radiotherapy treatment.

A questionnaire prepared by the researcher, based on the questionnaires EORTC QLQ-C30 (version 3) and EORTC QLQ-BR23 (3) was used as a research 
tool. It was composed of two parts: the first relating to general information about the interviewee, and the second with 36 structured and open-ended questions. These questions contemplated personal aspects that could influence the quality of life of women with breast cancer, which were used as categories for the presentation and analysis of results. The questionnaire was submitted to a pilot test with two women to check its applicability.

Initially, access was given to the nominal list of 25 participants of the group and telephone numbers of 15 of them. The researchers tried to make contact with all women. Thirteen responded: three did not meet the inclusion criteria and the other ten agreed to participate. The researcher attended some meetings of the support group for breast cancer patients the "Reborn" group — to facilitate approach with these women.

Interviews were conducted at home by the researcher in February and March, 2010, with exception for one of them, which was held at the hospital.

After the agreement and signing of an informed consent form, an interview was conducted and recorded on audio. Data were subsequently transcribed and qualitatively analyzed according to the systematization proposed by Minayo (4).

\section{Results and discussion}

The general characteristics of the ten women in this study are presented as follows. The age range was from 46 to 77 years; five were married, four were widowed and one was divorced. All of them had between one and four children. Regarding education, three of these women had incomplete primary education, three had completed primary education, three had completed high school and one of them completed higher education. Four women were housewives, six worked outside the home and one was retired.

Time elapsed since surgery varied from one to 21 years. Six women were mastectomized on their right. Four had done breast reconstruction and, among these, three with abdominal flap and one with silicone prosthesis implant. Nine women needed adjuvant treatment (chemotherapy, radiotherapy and/or hormone therapy) and one of them only had surgery. Eight respondents underwent physical therapy for a variable period of time and at different postoperative periods.
The study results will be presented by analysis categories and discussed below.

\section{Knowledge about breast cancer}

In the category related to breast cancer, treatment and consequences, the interviewees' knowledge on the aspects related to the disease was verified.

When asked about what idea they had about cancer at the time they were diagnosed, most considered cancer a fatal disease, as noted in the following reports.

"I thought it was something that had no solution... but when it's found early it has a 98\% chance of cure [...]" (I2).

"I didn't have much knowledge about it. As I said, you didn't hear a lot about breast cancer [...]" (I3).

The initial negative impact regarding the diagnosis of breast cancer is present in several other studies $(5,6,7,8,9,10)$, and this impact is usually related to two factors: patient's encountering of vulnerability and finitude; and the stigma that is still associated to the disease $(11,12,13,14)$.

A change was noticed in the notion about breast cancer and its treatment for most of the interviewees. This may have been motivated by the wider dissemination and guidance regarding treatment and related care in recent years, as well as participation in the "Reborn” group.

All women reported that over time they asked questions about their doubts, and these were answered by health professionals or support group members. Reasons for the absence of questions about cancer also included its treatment and consequences, the fact that they have already experienced cases of cancer in the family or among friends and/or have researched on the topic.

"I didn't know anything, I was learning as each new
phase came" (I4).
"I had a lot of questions [...] and then, over time, with
the professionals, we start to learn [...] with our meet-
ings as well [...]" (I6).

According to Ramos and Lustosa (15), the search for information is a way to keep self-control in these situations. 
Two women believed that the lack of knowledge they had about cancer, at the time of treatment, served as protection for them not to worry or suffer and to better cope with the situation, as one of them reported.

"[...] I didn't take the disease as seriously as it was because I didn't have much knowledge, so I think that's what helped me overcome everything. Some days, yes, I was scared: 'Will I die?', but then again, no" (I3).

Pinto and Gióia-Martins (9) point out that they observed the acceptance of this illness related to the ignorance about breast cancer, which, for the authors, reinforces the need for psychological work and elucidation about the disease.

Another aspect related to mastectomy that needs elucidation is the phantom breast syndrome. In this study, there were two breast phantom sensation reports.

"I had that tingling, a numbness for a long time" (I1). "I felt it and still feel it today. The nipples itch. I have no idea what it is, but I feel an itch inside, a feeling of malaise" (I5).

Breast phantom sensation means the persistence of breast sensation, itching, weight or tingling throughout the phantom breast or nipple-areolar region; feeling of pain in the phantom breast or phantom breast syndrome also occurs, which is the presence of sensations and breast pain after amputation (16). In the study of Silva et al. (17) with 98 women with breast cancer, only $3 \%$ of them had knowledge the phantom breast syndrome, which shows the need for health professionals to expose this situation for women who are operated for breast cancer.

Some interviewees showed at times lack of knowledge or prejudice against cancer and/or its treatment, at other times they observed the existence of ignorance or prejudice from society, present in their speeches as quotes from misconceptions about cancer, such as the existence of healing only at an early stage of the disease, and the need to hide their hair loss, as their own prejudice, fear or worry of suffering any prejudice from others.

"[...] a scarf is the label. It is written in your forehead 'undergoing chemotherapy' [...] looking at a bald person on the street offends, and I didn't want to offend anyone [...]" (I7).

\section{Participation in the "Reborn" support group}

As previously reported, women received support from family and friends and it was important for their recovery. Participation in the "Reborn" group also contributed to this recovery, as the following reports show.

"[...] we go there and talk. There are things we don't know yet, and at the same time we give support to people who recently found out, who still don't know [...] sometimes they're really downcast [...]" (I3).

Pinho et al. (8), conducted a study with mastectomized women participating in a support group and found that most had positive thinking towards the disease and relied on healing and struggle for life, corroborating to the results of this study, presented above. Gomes et al. (18), on a review about support groups for women with breast cancer, concluded that spending time with other women with similar stories allows dealing with situations that breast cancer brings to these women's lives, besides expanding their social network, decreasing the feeling of isolation and loneliness.

In the support group for mastectomized women they have the opportunity to identify themselves, exchange experiences, ease tensions, understand the condition they are going through, keep themselves informed and enlightened about cancer and its treatment, and build bonds of friendships, reflect about life events and raise self-esteem and quality of life (19).

This study showed that, for some women, the "Reborn" group is the only place they talk about cancer, or where they feel more comfortable to talk about it. These women were more likely to talk about the disease with health professionals, or other women going through the same struggle, than with their own family and people they spent most time with.

There was also support from health professionals who treat these women, and they pointed out the existence of affective bonds between them. According to Kappaun and Ferreira (20), health professionals who deal with mastectomized women play an important role in embracing them, listening to them and easing their doubts. For Moura et al. (21), care for these 
women is essential for them to recognize the frame they experience, which is possible with the support of the multidisciplinary team providing information about cancer, surgery, treatment, possible aesthetic interventions, thus helping to decrease feelings of doubt, fear, worry and nervousness generated by the lack of support and help.

“[...] when I joined the group, I wasn't looking for affection, I was looking for professionals [...] and I found excellent professionals, and also affection" (I7).

Women who underwent physical therapy said it was important for their recovery.

"[...] when we do it (the surgery), we're afraid of how far we can go not to cause ourselves any harm, and with the physical therapy you do know how far you can go. I have all my movements normally, as if nothing had happened, all thanks to the physical therapy" (I4).

"[...] I felt that part dormant, and once I told the group I had no sensitivity in that part [...] then I started doing it (physical therapy) [...] and it was awesome, I began to feel it [...]" (I6).

To Moreira and Manaia (22), physical therapy promotes the improvement or reduction of motion dysfunction and muscle strength of the scapular waist and the postural correction/rehabilitation, improves bodily image and self-esteem and also acts to relieve discomfort caused by the treatment.

Jammal et al. (23), in their review, concluded that physical therapy brings benefits to mastectomized women including avoiding or minimizing postoperative complications, reducing recovery time and facilitating a faster return to their daily and occupational activities while maintaining or increasing quality of life.

\section{Conclusion}

Breast cancer is a disease about which there are still many doubts and prejudices.

This study identified a change of concepts and ideas about cancer for the interviewed women, and the importance for breast cancer patients to receive information and explanations about cancer, its treatment and consequences, by health professionals. The importance of the support group in the recovery of these women was also emphasized, for the opportunity to spend time with other people with similar stories.

This study is relevant for presenting situations and difficulties experienced by mastectomized women to physical therapists and other health professionals, in order to be considered as an aid to physical and emotional recovery of these women.

\section{References}

1. Instituto Nacional de Câncer [internet]. Brasília: Ministério da Saúde; 1996 [cited 2009 Jun 21]. Available from: www.inca.gov.br

2. Correia GN, Oliveira J, Mesquita-Ferrari RA. Avaliação da qualidade de vida em mulheres submetidas à mastectomia radical e segmentar. Fisioter Pesqui. 2007;14(3):31-6.

3. European Organization for Research and Treatment of Cancer [internet]. Brussels: EORTC; 2009 [cited 2009 Jun 21]. Available from: http://www.eortc.org/

4. Minayo MCS. O desafio do conhecimento: pesquisa qualitativa em saúde. São Paulo: Hucitec; Rio de Janeiro: Abrasco; 1992.

5. Duarte TP, Andrade NA. Enfrentando a mastectomia: análise dos relatos de mulheres mastectomizadas sobre questões ligadas à sexualidade. Estud. Psicol. 2003;8(1):155-63.

6. Silva G, Santos MA. "Será que não vai acabar nunca?": perscrutando o universo do pós-tratamento do câncer de mama. Texto Contexto Enferm. 2008;17(3):561-8.

7. Huguet PR, Morais SS, Osis MJD, Pinto-Neto AM, Gurgel MSC. Qualidade de vida e sexualidade de mulheres tratadas de câncer de mama. Rev Bras Ginecol Obstet. 2009;31(2):61-7.

8. Pinho LS, Campos ACS, Fernandes AFC, Lobo AS. Câncer de mama: da descoberta à recorrência da doença. Rev Eletrônica enferm. 2007;9(1):154-5.

9. Pinto AC, Gióia-Martins DF. Qualidade de vida subseqüente à mastectomia: subsídios para intervenção psicológica. Rev SBPH. 2006;9(2):3-27. 
10. Talhaferro B, Lemos SS, Oliveira E. Mastectomia e suas conseqüências na vida da mulher. Arq Ciênc Saúde. 2007;14(1):17-22.

11. Amara AV, Melo RMM, Santos NO, Lôbo RCMM, Benute GRG, Lucia MCS. Qualidade de vida em mulheres mastectomizadas: as marcas de uma nova identidade impressa no corpo. Psicol Hosp. 2009;7(2);36-54.

12. Ferreira MLSM, Mamede MV. Representação do corpo na relação consigo mesma após mastectomia. Revista Lat Am Enfermagem. 2003;11(3);299-304.

13. Hoffmann FS, Müller MC, Rubin R. A mulher com câncer de mama: apoio social e espiritualidade. Mudanças. 2006;14(2):143-50.

14. Ferreira CB, Almeida AM, Rasera EF. Sentidos do diagnóstico por câncer de mama feminino para casais que o vivenciaram. Interface. 2008;12(27):863-71.

15. Ramos BF, Lustosa MA. Câncer de mama feminino e psicologia. Rev SBPH. 2009;12(1):85-97.

16. Ferraz NM. Mama fantasma no pós-operatório de mastectomia radical modificada [tese]. Brasília: Universidade de Brasília; 2007.

17. da Silva BB, Mendes LCM, Costa NKB, Holanda LGM, Lima GP, Teles JBM, et al. Síndrome da mama fantasma: características clínicas e epidemiológicas. Rev Bras Ginecol Obstet. 2007;29(9):446-51.

18. Gomes FA, Panobianco MS, Ferreira CB, Kebbe LM, Meirelles MCCC. Utilização de grupos na reabilitação de mulheres com câncer de mama. Rev Enfermagem UERJ. 2003;11(3):292-5.
19. Stumm EMF, Maçalai C, Leite MT, Loro MM. Mecanismos de coping utilizados por mulheres mastectomizadas para lidar com o estresse. Sci Med. 2009;19(3):108-14.

20. Kappaun NRC, Ferreira MEC. A imagem corporal de mulheres mastectomizadas. HU Rev. 2008; 34(4):243-8.

21. Moura FMJSP, Moura MG, Oliveira SC, Moura LJSP. Os sentimentos das mulheres pós-mastectomizadas. Esc Anna Nery. 2010;14 (3):477-84.

22. Moreira ECH, Manaia CAR. Qualidade de vida das pacientes mastectomizadas atendidas pelo serviço de fisioterapia do Hospital Universitário da Universidade Estadual de Londrina. Semina Cienc Biol Saude. 2005;26(1):21-30.

23. Jammal MP, Machado ARM, Rodrigues LR. Fisioterapia na reabilitação de mulheres operadas por câncer de mama. Mundo Saúde. 2008;32(4):506-10.

Received: 08/24/2012

Recebido: 24/08/2012

Approved: 04/07/2015

Aprovado: 07/04/2015 